\title{
New Breakthrough of British and American Literature Teaching
}

\author{
XU Li-mei, QU Lin-lin \\ Changchun University, Changchun, China
}

\begin{abstract}
Under the impact of the market economy, the British and American literature course was marginalized to some extent. In response to this phenomenon, the author will contrastively demonstrate the "perfect" education in aesthetic education and the teaching objectives of British and American literature course. This paper points out the meaning of deepening literature teaching from the view of aesthetic education, and puts forward specific suggestions on how to implement aesthetic education in literature class, so as to provide some ideas for the trend of the development of the British and American literature course.
\end{abstract}

Keywords: aesthetic education, English and American literature, breakthrough

\section{Introduction}

With the environment of social need for generalists, the situation of English and American literature teaching in higher school is not optimistic. Both the low quality of teachers and the lack of interest and energy investment of students make it difficult for British and American literature to achieve teaching purposes of improving the humanistic quality of the students. This shows that the British and American literature teaching must realize the new breakthrough, further implement the teaching reform, thus highlighting the role of the British and American literature in improving the quality of the humanities.

\section{The Importance of the Aesthetic Education in Foreign Language Teaching}

On the "aesthetic education", professor Binet Alfred (1916) discussed the essence, form theory and aesthetic theory of the beauty in "Aesthetic Conspectus". At the same time, the personnel training mode reform of Ministry Education and open education pilot textbook will also present and sum up a common understanding of "aesthetic education" in four aspects. Namely aesthetic education refers to the education of perfect talent, value and art education, aesthetic theory, as well as the aesthetic feeling. It can be seen composting the understanding of these different levels that aesthetic education not only refers to the specific artistic training and specialized technical training, but also refers to the comprehensive perfect education.

Actually, as early as in 1793, Campbell, the representative of German classical literature and classical aesthetics, has made serious thinking on the perfect education. The 27 letters written to the prince of Denmark, Schiller discussed the improvement of human perfection, the fate of human, and the social improvement making aesthetics as the basis. The letters with flashing wisdom were arranged into the "On the Aesthetic Education of

XU Li-mei, lecturer, Ph.D. candidate, Foreign Languages College, Changchun University.

QU Lin-lin, lecturer, Ph.D. candidate, Foreign Languages College, Changchun University. 
Man”, which was the first programmatic document in the modern aesthetic criticism.

It not only marks the formation of independent theoretical system of aesthetic education, but also learns the aesthetic education pioneering putting it in an all-round way height. Under the influence of Schiller, the world's understanding of aesthetic education has extended to the education formed in the combination of the teaching of all subjects with aesthetic education from art education. As the cradle of personnel training, colleges and universities should correctly grasp the essence of aesthetic education and should be neither controlled in the impact of the market economy, nor constrained by the specialized and professional guidance, but making it as a systematic project, and full ranging infiltrated into many specific subject areas. Thus college students will promote their personality and become a "perfect" person with beauty and ability in the compulsion of beauty.

\section{Organic Combination of British and American Literature With Aesthetic Education}

\section{Teaching Objectives of English and American Literature}

Although the emphasis of the teaching guide of ESP (English for special purposes) is a change to adapt to the requirements of the times, the process of strengthening pragmatic teaching should never neglected the diversified teaching purpose of English and American literature course. Because the course characteristics and teaching content of the British and American literature course fit in with the teaching concept of aesthetic education. Gass and Mackey have pointed out that:

The purpose of the British and American literature course is to train the ability of the students in English literature reading, appreciating, and understanding, and to grasp the basic knowledge and methods of literature criticism. Through reading and analyzing the works of English and American literature, students will improve their language skills and human quality, and they will also enhance their understanding of the western literature and culture. (Gass \& Mackey, 1999)

It is visible that the purpose of teaching English and American literature course lies not only in improving the English language ability of students, but more in improving the humanistic quality of students through the literature teaching, especially cultural quality, so as to cultivate high quality talents who have highly humane care and good cultural accomplishment, which undoubtedly is the specific interpretation of "perfect education".

\section{The Mutual Infiltration of English and American Literature Teaching and Aesthetic Education}

Literature is an aesthetic art, which is rich in emotion, vivid image, and free state. This character means that the educational function of literary works is at the core of literary aesthetic psychology. As a teacher of English majors, the author believes that the sense of humanities in the literature is just the "beauty" of language learning. So the organic combination of aesthetic education and literature course will penetrate the principle of aesthetic education into the teaching to help college students in the critical period of mental maturity and personality shaping beyond literary readings, and create healthy personality through aesthetic experience. Specifically, on the one hand, the academic factors, employment, interpersonal factors, self realization, and other factors will bring great pressure on the students, which will make the students prone to various psychological problems. As the art of language, the reflection of the product and life of the consciousness, literary works is a kind of life style and attitude of life in essence. It can be regarded as a kind of belief in life. Good literary works can make the reader experience life taste, develop thinking, and perfect personality. Therefore, it is of important practical significance to make full excavation of the literary beauty of humanity, to promote the aesthetic education to help 
the students ease their anxiety, and to enhance their living wisdom.

On the other hand, developing literature by aesthetic education can effectively promote the reform of the teaching of English and American literature. At present, there are a lot of problems in the teaching of literature. According to the survey, students of different language levels and teachers of different teaching styles hope to use effective teaching materials, but at present, more than a dozen kinds of British and American literature teaching in China cannot meet the needs. Many teachers think the current textbooks are old-fashioned on the system and view, and lack of novelty and readability. The existence of these problems causes the disconnection between literature knowledge and the improvement of the students' humanistic quality, which is another important reason for the literature course being marginalized. Besides that, the conservative teaching method is another problem in British and American literature teaching. The author found that the literature teaching still stays in the introduction of the language characteristics, themes, writing style, the author's life background, and other forms of the work. This interpretation of Dragonfly water type make literature class become a replica of the extensive reading class to a certain extent, which directly leads to the lack of the subject status for students, and deviates from the theme of literature teaching. In fact, these problems ignore the interaction between the literature and the students, so that many students think that the course of literature is far from the reality, and there is no real role to learn. How to do the way out of literature, the combination of aesthetic education and literature is a new breakthrough to deepen the literature course.

\section{How to Promote the Teaching of English and American Literature by Aesthetic Education}

It is of obvious practical significance to push forward the teaching of British and American literature from the perspective of aesthetic education, but there are many difficulties in the operation. For example, the aesthetic ideas of the teachers are weak in the course of literature. Many literature teachers are influenced by the traditional teaching, and the appreciation of literary works is more than the work style. In addition, it is difficult to design the literature problem making the teaching of aesthetic education as the guidance. Because these questions not only point to the text content, but also to the students' inner literary experience and aesthetic consciousness. Besides that, the students' ability of English expression is weak, both the little literature class and the limited classroom time bring challenges to the teaching reform of the teachers.

As for how to effectively play the function of aesthetic education, and promote the teaching of British and American literature, the following specific recommendations are for reference.

\section{Enhance the Teacher's Aesthetic Ideas}

Enhance the teachers' aesthetic standard from the aspects of self-cultivation, speech and deportment, appreciation of aesthetics, philosophy of education by encouraging them reading aesthetic education textbooks and articles, learning, classroom observation, and interviews. This method will imperceptibly guide students to consciously aesthetic education.

\section{Choose Reasonable Text}

The teachers should choose reasonable text according to the arrangement of the class hours, the students' actual language level, and the choice of reading interest. The text should focus on the times (such as the British and American literature since the 20th century), the diversity of form (such as novels, poems, plays, etc.), and the 
theme of the times (such as the tribute to the great self, the understanding of the theme of "brave"). Besides that, text should also highlight the goal of aesthetic education, and treat the students with the spirit of enjoyment and pleasure as far as possible, which will stimulate the students' emotional experience, and ease their psychological pressure.

\section{Renew Teaching Ideas}

It is suggested that teachers should make research on how to break the traditional method of literature curriculum making literature, text, and even the language knowledge as the teaching target. At the same time, the teachers should also make research on how to develop the students' cultural quality and human spirit by introducing the western modern literary theories in simple language based on the development of the students. Based on this idea, teachers can initiate research-based learning, put focus on how to cultivate the students' main practical ability, such as the ability of collecting information, analyzing the problems, cooperating, and innovating.

\section{Diversification of Assessment Methods}

It is suggested that teachers should study the open examination mode, and combine the final exam with the term papers and the usual reading reports. At the same time, they can also join the performance of the classroom performance, so that the evaluation results are more accurate, objective, and effective, which can mobilize the interest of the students to learn English and American literature courses, cultivate more independent students with innovative thinking ability.

\section{Conclusion}

In short, aesthetics will influence the education concept, while the education concept would influence of teachers' teaching methods and the students' learning strategies and learning methods. The teaching of English and American literature is faced with challenges and difficulties. The traditional teaching mode must gain new breakthrough as soon as possible to improve the quality of teachers, stimulate students' interest in learning, and improve the students' theoretical training, thinking ability, and comprehensive humanistic quality. Only by obtaining a new breakthrough in the teaching process, can students be taught basic knowledge and students' humanistic quality can be cultivated, thus cultivating foreign language talents with solid basic skills of language.

\section{References}

Binet, A. (1916). New methods for the diagnosis of the intellectual level of subnormals. In E. S. Kite (Trans.), The development of intelligence in children. Vineland, NJ: Publications of the Training School at Vineland.

Campbell, L. (1999). Multiple intelligences and student achievement: Success stories from six schools. Alexandria, Virginia: Association for Supervision and Curriculum Development.

Cook, G., \& Seidlhofer, B. (1999). Principles and practice in applied linguistics. Shanghai: Shanghai Foreign Language Education Press.

Dubin, F., \& Olshetain, E. (2002). Course design. Shanghai: Shanghai Foreign Language Education Press.

Duff, P. A. (2011). Case study research in applied linguistics. Beijing: Foreign Language Teaching and Research Press.

Ellis, R. (1999). The study of second language acquisition. Shanghai: Shanghai Foreign Language Education Press.

Gass, S. M., \& Mackey, A. (2011). Data elicitation for second and foreign language research. Beijing: Foreign Language Teaching and Research Press.

Gottfredson, L. S. (1997). Mainstream science on intelligence (on-line). Foreign Literature, 58(24), 13-23. 